\title{
ANALISIS KATA TUGAS PADA ARTIKEL OPINI "MELESTARIKAN BUDAYA, MEMANDIRIKAN WARGA" OLEH MUSONIF FADLI DALAM SURAT KABAR JAWAPOS
}

\author{
Hasnah Setiani ${ }^{1}$, Asep Purwo Yudi Utomo \\ ${ }^{1}$ Universitas Negeri Semarang, Gedung B1 Lantai 1 FBS UNNES, \\ hasnahsetiani8@gmail.com \\ ${ }^{2}$ Universitas Negeri Semarang, Gedung B1 Lantai 1 FBS UNNES, \\ aseppyu@mail.unnes.ac.id
}

\begin{abstract}
Syntax is a part of linguistics that studies sentences and the building blocks of a sentence. The units that build sentences include the units of words, phrases, clauses, and sentences. The units of phrases, clauses, and sentences will create syntactic units and express grammatical meanings using syntactic structures. The components that create the units of grammatical meaning or syntactic structures include (1) word order, (2) intonation, (3) word forms, and (4) function words. The function words is an important unit that arranges the accuracy of a sentence and the cohesiveness of a paragraph in discourse, including discourse in an opinion article. This study aims to identify each type of function word and its respective roles in composing the cohesiveness and continuity of a sentence to a paragraph in the opinion article "Memandirikan Budaya, Melestarikan Warga". This study used a qualitative descriptive approach. The descriptive approach method is a research method that is carried out by analyzing and describing the data to be used as research results in the form of word strings or series of sentences and not in the form of numbers or statistics. Based on the results of the analysis of the task words in the opinion article "Memandirikan Budaya, Melestarikan Warga", it was found that the types of function words were conjunctions, prepositions, and pronouns that function as explanations for the main words and composing sentences. The benefits of research are as a means of conveying the author's ideas, encouraging writers to think scientifically and systematically, and have an academic impact on readers.
\end{abstract}

Keyword(s): function words, opinion articles, conjunctions, prepositions, pronouns

\begin{abstract}
ABSTRAK
Sintaksis merupakan bagian dari ilmu linguistik yang mengkaji tentang kalimat dan unsur-unsur pembangun suatu kalimat tersebut. Satuan-satuan yang membangun kalimat meliputi satuan kata, frasa, klausa, dan kalimat. Satuan frasa, klausa, dan kalimat akan membentuk satuan sintaksis dan menyatakan makna gramatikal dengan alat sintaksis. Sarana-sarana yang mewujudkan satuan makna gramatikal atau alat-alat sintaksis tersebut meliputi (1) urutan penempatan kata, (2) intonasi, (3) bentuk kata, dan (4) kata tugas. Kata tugas merupakan satuan penting yang menyusun ketepatan kalimat dan kepaduan suatu paragraf dalam wacana, termasuk wacana dalam artikel opini. Penelitian ini bertujuan untuk mengidentifikasi masing-masing jenis kata tugas serta masing-masing peranannya dalam menyusun kepaduan dan kesinambungan suatu kalimat hingga paragraf dalam artikel opini "Melestarikan Budaya, Memandirikan Warga". Penelitian ini menggunakan metode pendekatan deskriptif berbentuk kualitatif. Metode pendekatan deskriptif merupakan metode penelitian yang dilakukan dengan cara menganalisis dan menguraikan data untuk dijadikan hasil penelitian dalam bentuk untaian kata atau rangkaian kalimat dan bukan berupa angka atau statistik. Berdasarkan hasil analisis kata tugas pada artikel opini "Melestarikan Budaya, Memandirikan Bangsa" ditemukan jenis kata tugas yaitu konjungsi, preposisi, dan pronomina yang berfungsi sebagai penjelas kata utama dan
\end{abstract}


penyusun kepaduan kalimat. Manfaat penelitian yaitu sebagai sarana untuk menyampaikan gagasan penulis, memberi dorongan bagi penulis untuk berpikir ilmiah dan sistematis, dan memberi dampak akademis bagi pembaca.

Kata Kunci : kata tugas, artikel opini, konjungsi, preposisi, pronomina

How to Cite: Hasnah Setiani, \& Purwo Yudi Utomo, A. (2021). Analisis ANALISIS KATA TUGAS PADA ARTIKEL OPINI "MELESTARIKAN BUDAYA, MEMANDIRIKAN WARGA" OLEH MUSONIF FADLI DALAM SURAT KABAR JAWAPOS . Bahtera Indonesia; Jurnal Penelitian Bahasa Dan Sastra Indonesia , 6(2), 103-119. https://doi.org/10.31943/bi.v6i2.104

\section{DOI: https://doi.org/10.31943/bi.v6i2.104}

\section{PENDAHULUAN}

Media informasi berupa surat kabar sebagai sarana penyajian informasi terkini yang siap membuka pengetahuan dan pandangan para pembaca. Ruang lingkup media informasi berupa surat kabar salah satunya yaitu artikel opini. Menurut Kuncoro (dalam Hasanah, 2017:13), artikel opini adalah tulisan lepas yang berisi opini seseorang yang mengupas tuntas satu masalah tertentu yang sifatnya aktual dan atau kontroversi dengan tujuan untuk memberi tahu, mempengaruhi, meyakinkan, dan atau menghibur pembaca. Peran para penyaji artikel opini harus selalu mengadirkan informasi dengan memperhatikan aspek isi dan bentuk yang mengacu pada kaidah kebahasaan yang baik dan benar agar terhindar dari kesalahan berbahasa. Kesalahan berbahasa merupakan peristiwa yang bersifat inheren (erat kaitannya) dalam setiap pemakaian bahasa baik pemakaian lisan maupun tertulis (Supriani dalam Utomo, 2019:235). Artikel opini merupakan bentuk pemakaian bahasa tertulis untuk mengungkapkan informasi sehingga harus memperhatikan konstruksi kalimat agar dapat tercipta kepaduan dan kefektifan kalimat. Hal tersebut menyangkut keilmuan bidang linguistik atau ilmu tentang bahasa khususnya kajian sintaksis.

Sintaksis adalah cabang ilmu bahasa yang memfokuskan kajian tentang kalimat. Suhardi (2013:13) mendefinisikan pengertian sintaksis secara lengkap yaitu sintaksis sering disebut ilmu tata kalimat. Ilmu yang memfokuskan kajiannya pada kata, kelompok kata, klausa, yang berkaitan dengan jenisjenis kalimat. Satuan frasa, klausa, dan kalimat akan membentuk kesatuan sintaksis dan menyatakan makna gramatikal dengan alat sintaksis. Frasa, klausa, dan kalimat tidak secara tiba-tiba muncul tanpa adanya sarana yang menunjang terwujudnya satuan-satuan tersebut. Perangkat-perangkat yang menjadi 
sarana terwujudnya satuan-satuan disebut dengan alat sintaksis (Febriani, 2016).

Alat-alat sintaksis berperan sebagai penentu suatu kalimat memiliki makna gramatikal dan dapat menentukan apakah rangkaian konstituen mengandung makna atau tidak. Sarana-sarana yang mewujudkan satuan makna gramatikal atau disebut dengan alat-alat sintaksis tersebut meliputi (1) urutan penempatan kata, (2) intonasi, (3) bentuk kata, dan (4) kata tugas. Alat sintaksis berupa kata tugas merupakan kata yang tidak bermakna jika berdiri sendiri tetapi akan memiliki makna jika dirangkai dengan kata lain dalam satuan frasa, klausa, atau kalimat. Menurut Chaer (dalam Pratami, 2016:162), kata tugas adalah kata yang secara inhern tidak mempunyai makna, hanya memiliki tugas dalam sintaksis. Jadi, dapat disimpulkan bahwa kata tugas adalah kata yang tidak mempunyai arti atau makna jika berdiri sendiri tetapi akan memiliki arti jika dirangkai dengan kata lain dalam frasa atau kalimat. Kata tugas hanya bermakna gramatikal dan tidak mempunyai makna leksikal (Muchlis dalam Masitoh, 2019:151).

Penelitian ini terkait dengan penelitian sebelumnya, yaitu penelitian yang dilakukan oleh Intan Pratami, Emidar, dan Ellya Ratna tahun 2016 terkait dengan analisis kesalahan penggunaan kata tugas pada teks eksposisi siswa. Pada penelitian ini akan dikemukakan identifikasi jenis-jenis kata tugas pada artikel opini dan masing-masing peranannya dalam menyusun kepaduan dan kesinambungan sebuah wacana pada artikel opini yang dianalisis. Penelitian ini memiliki perbedaan dalam analisis masalah yang diungkapkan pada penelitian sebelumnya. Jika pada penelitian sebelumnya permasalahan yang diangkat berupa analisis kesalahan penggunaan kata tugas pada suatu teks, maka pada penelitian ini akan diuraikan hasil analisis berupa jenis kata tugas dan perannya dalam artikel opini. Pada penelitian ini akan dikaji jenis-jenis kata tugas meliputi (1) preposisi, (2) konjungsi, dan (3) pronomina.

Penulis melakukan penelitian dengan menganalisis kata tugas pada artikel opini "Melestarikan Budaya, Memandirikan Warga" mengingat pentingnya setiap satuansatuan yang menyusun kalimat sehingga perlu diperhatikan agar kalimat memiliki makna gramatikal dan memiliki kepaduan kalimat hingga paragraf dalam wacana, khususnya wacana artikel opini dalam surat kabar. Tanpa adanya alat sintaksis termasuk peran kata tugas, suatu kalimat menjadi tidak efektif yang menyebabkan pembaca tidak dapat memahami informasi yang tersaji dalam artikel opini surat kabar. Penulis melakukan penelitian ini dengan tujuan mengidentifikasi jenis-jenis kata tugas serta masing-masing peranannya dalam menyusun kepaduan dan kesinambungan suatu kalimat hingga paragraf dalam artikel opini surat kabar. Dari hasil 
penelitian yang dilakukan, harapannya dapat memberi manfaat bagi penulis maupun bagi pembaca yaitu sebagai sarana untuk menyampaikan gagasan penulis, memberi dorongan bagi penulis untuk berpikir ilmiah dan sistematis dan memberi dampak akademis bagi pembaca terutama dalam etika kebahasaan yang baik dan benar. Hasil analisis dalam penelitian ini diharapkan dapat membuka pengetahuan pembaca terkait pentingnya peran kata tugas dalam penyusunan wacana surat kabar khususnya dalam suatu artikel.

\section{METODE PENELITIAN}

Penulis menggunakan dua metode pendekatan dalam proses penelitian ini (1) metode penghimpunan data, dan (2) metode penguraian data. Metode penghimpunan data dengan menggunakan metode dokumenter, sedangkan metode penguraian data menggunakan metode deskriptif untuk medeskripsikan data. Metode deskriptif merupakan langkah-langkah penelitian dengan menguraikan data dalam bentuk rangkaian kata atau kalimat. Bentuk penelitian ini merupakan penelitian yang menggunakan metode pendekatan kualitatif. Metode kualitatif merupakan langkah penelitian untuk menghasilkan data secara deskriptif yang berupa kata berdasarkan hasil identifikasi terhadap artikel opini. Sumber data yang mendukung analisis terhadap jenis- jenis kata tugas pada artikel opini adalah surat kabar Jawapos. Sumber data berupa artikel dan jurnal online juga digunakan untuk analisis hasil penelitian.

Penulis menggunakan teknik dokumenter yang digunakan dalam proses pengumpulan data. Studi dokumenter merupakan suatu cara mengumpulkan data dan fakta dengan menemukan, menghimpun, kemudian menganalisis sumber literatur, baik dalam bentuk tertulis maupun non tulis. Langkah-langkah menggunakan teknik dokumenter dalam proses penghimpunan data yaitu: (1) Membaca artikel opini "Melestarikan Budaya, Memandirikan Warga" oleh Musonif Fadli dalam Surat Kabar Jawapos yang menjadi sumber data utama dalam penelitian,

Mengelompokkan kata yang termasuk jenis kata tugas konjungsi, preposisi, dan pronomina (3) Mencatat data yang sudah dikelompokkan dalam kategori konjungsi, preposisi, dan pronomina, Mengidentifikasi jenis masing-masing kategori kata tugas yang sudah dikelompokan dalam kategori preposisi, konjungsi, dan pronomina, (5) Menganalisis peran penggunaan preposisi, konjungsi, dan pronomina (6) menarik kesimpulan dari hasil penelitian berdasarkan penemuan jenis-jenis kata tugas dalam artikel opini yang diteliti. Penulis sendiri sebagai alat pengumpul data. Penulis menjadi instrumen yang bertugas 
dalam merencana, melaksanakan, penelitian ini akan diuraikan secara mengumpulkan, menafsirkan, dan mendalam terkait setiap kata yang ditemukan melaporkan data hasil penelitian. Teknik dalam artikel yang termasuk dalam kategori analisis data yang dipilih untuk menganalisis jenis kata tugas serta masing-masing kata tugas pada artikel opini surat kabar ini peranannya dalam menyusun wacana artikel adalah teknik kualitatif. Teknik kualitatif berdasarkan jenis dan sub jenis. Saputra Yogi merupakan upaya menganalisis sumber data dengan cara mendalami data, dalam situs mengklasifikasikan data, memilah, https://majalahpendidikan.com/kata-tugas/ mengidentifikasi pola, dan memutuskan sesuatu yang penting dan harus diuraikan untuk dapat dibagikan kepada orang lain. Penulis melakukan analisis dengan membaca artikel opini pada surat kabar secara teliti dan berulang, mengidentifikasi jenis masingmasing kata tugas, menganalisis hasil identifikasi, serta menarik kesimpulan dari hasil penelitian.

\section{HASIL DAN PEMBAHASAN}

Berdasarkan rumusan masalah dan tujuan penelitian, diuraikan hasil penelitian dan pembahasan tentang jenis kata tugas meliputi preposisi, konjungsi, dan pronomina serta masing-masing peranannya dalam menyusun kepaduan dan kesinambungan sebuah wacana pada artikel opini "Melestarikan Budaya, Memandirikan Warga" dalam surat kabar Jawapos. Hasil analisisnya adalah (1) hasil identifikasi jenis kata tugas preposisi, (2) hasil identifikasi jenis kata tugas konjungsi, dan (3) hasil identifikasi jenis kata tugas pronomina. Dalam hasil

\section{Hasil Identifikasi Jenis Kata Tugas Preposisi}

Menurut Finzoa (dalam Zulfatun, 2019:17), preposisi merupakan jenis kata tugas yang selalu berada di depan kata benda, kata kerja, kata sifat atau kata keterangan. Adapun menurut Efendi (dalam Sugiarti, 2018:126), preposisi adalah kata depan yang pelengkap dan porosnya menghubungkan dengan kata leksikal lain yang mendahuluinya dalam suatu konstruksi gramatikal untuk 
menyatakan makna. Sedangkan Chaer (2009:108) mengemukakan bahwa preposisi atau kata depan merupakan kata yang berada di sebelah kiri nomina, sehingga akan membentuk frasa eksosentrik yang mengisi fungsi keterangan dalam suatu kalimat atau frasa. Menurut Ramlan dalam Kelas Kata Bahasa Indonesia (2009: 24), secara semantik kata depan dapat digunakan untuk menandai makna. Jenis preposisi terdiri atas preposisi yang menyatakan makna (a) tempat, (b) arah asal, (c) arah tujuan, (d) perbandingan, (e) pelaku, (f) alat/cara, (g) hal, (h) pembatasan, dan (i) tujuan.

Preposisi ditemukan pada artikel opini "Melestarikan Budaya, Memandirikan Warga" dalam surat kabar Jawapos berupa preposisi yang menyatakan cara, preposisi (kata depan) yang menyatakan tempat, preposisi (kata depan) yang menyatakan pembatasan, preposisi (kata depan) yang menyatakan arah tujuan, preposisi (kata depan) yang menyatakan pelaku, dan preposisi yang menyatakan asal.

Tabel 1. Jumlah Kata Tugas Jenis

Preposisi dalam Artikel

\begin{tabular}{|l|lr|l|}
\hline No & Jenis Preposisi yang & J data \\
\hline 1 & $\begin{array}{l}\text { Preposisi } \\
\text { menyatakan cara }\end{array}$ & 3 data \\
\hline 2 & $\begin{array}{l}\text { Preposisi yang } \\
\text { menyatakan tempat }\end{array}$ & \\
\hline
\end{tabular}

\begin{tabular}{|l|lr|l|}
\hline 3 & \multicolumn{2}{|l|}{$\begin{array}{l}\text { Preposisi yang } \\
\text { menyatakan pembatasan }\end{array}$} & 2 data \\
\hline 4 & $\begin{array}{l}\text { Preposisi yang } \\
\text { menyatakan arah tujuan }\end{array}$ & 1 data \\
\hline 5 & $\begin{array}{l}\text { Preposisi yang } \\
\text { menyatakan pelaku }\end{array}$ & 1 data \\
\hline 6 & $\begin{array}{l}\text { Preposisi } \\
\text { menyatakan asal yang }\end{array}$ & data \\
\hline \multicolumn{2}{|c|}{ Total } \\
\hline
\end{tabular}

Preposisi yang Menyatakan Cara

Preposisi menyatakan cara yaitu dengan dan berkat. Bentuk preposisi yang menyatakan cara ditemukan pada artikel opini "Melestarikan Budaya, Memandirikan Warga" yang ditandai dengan kata dengan. Kata dengan merupakan preposisi yang memberikan keterangan bagaimana sesuatu terjadi atau suatu tindakan dilakukan. Terdapat preposisi yang menyatakan cara yang ditandai dengan kata dengan sebanyak 6 data.

"Namun, sejauh ini Banyuwangi dengan penggalian lokalitas dan kreativitas dalam pengemasannya perlu dijadikan acuan bagi daerah lain. Tek heran jika Banyuwangi yang dipimpin Bupati Azwar Anas dinobatkan sebagai 'The Best Festival City' oleh Kementerian Pariwisata." (Fadli, 2017)

Penggalan wacana di atas terdapat kata tugas jenis preposisi yang menyatakan cara yang ditandai dengan kata dengan. Kata dengan dalam kutipan tersebut menyatakan suatu cara yang dilakukan oleh daerah 
Banyuwangi yang menjadi acuan bagi daerah lain yaitu dengan cara penggalian lokalitas dan kreativitas.

\section{Preposisi yang Menyatakan Tempat}

Chaer (2009:108) menyatakan bahwa preposisi yang menyatakan makna tempat yaitu pada, di, atas, dalam, dan antara. Preposisi yang menyatakan tempat ditemukan pada artikel opini "Melestarikan Budaya, Memandirikan Warga" yang ditandai dengan kata di dan dalam. Kata di dan dalam merupakan preposisi yang menandai pertalian makna keberadaan atau suatu tempat. Terdapat preposisi yang menyatakan tempat yang ditandai dengan kata $d i$ dan dalam sebanyak 3 data.

"Poin tersebut menekankan bahwa pemahaman atas kearifan lokal harus dijadikan acuan pembangunan di daerah. Pemahaman atas budaya lokal dapat dijadikan rule model untuk menata sesuai dengan lokalitasnya." (Fadli, 2017)

Penggalan wacana di atas terdapat kata tugas jenis preposisi yang menyatakan tempat yang ditandai dengan kata $d i$. Kata depan $d i$ selalu diikuti keterangan tempat dan penlisannya dipisah dari kata yang mendahuluinya (Trim dalam Isnaini, 2018:3). Kata $d i$ dalam kutipan tersebut menandai keberadaan tempat yang menjadi acuan pembangunan dengan pemahaman atas kearifan lokal yaitu dititikberatkan di daerah.
"Bahkan, lebih dari itu, Gidden (1991) menyatakan, ini untuk kali pertama dalam sejarah manusia, 'diri' dan 'masyarakat' saling berhubungan di dalam satu lingkungan global.” (Fadli, 2017)

Penggalan wacana si atas terdapat kata tugas jenis preposisi yang menyatakan tempat yang ditandai dengan kata dalam. Kata dalam dalam kutipan tersebut menandai suatu tempat terjadinya hubungan sejarah informasi seperti pada data di atas yang terjadi dalam suatu lingkup global.

\section{Preposisi yang Menyatakan Pembatasan}

Chaer (2009:108) menyatakan bahwa preposisi yang menyatakan pembatasan yaitu sampai dan hingga/sehingga. Preposisi yang menyatakan pembatasan ditemukan pada artikel opini "Melestarikan Budaya, Memandirikan Warga" yang ditandai dengan kata hingga dan sampai. Kata hingga dan sampai merupakan preposisi yang menandai suatu batas akhir. Terdapat preposisi yang menyatakan pembatasan yang ditandai dengan kata hingga dan kata sampai sebanyak 2 data.

"Tercatat, event yang disandingkan dari tahun ke tahun terus bertambah. Hingga 2017 ini, event yang sandingkan mencapai 72 event." (Fadli, 2017)

Penggalan wacana di atas terdapat kata tugas jenis preposisi yang menyatakan pembatasan yang ditandai dengan kata hingga. Kata hingga dalam kutipan tersebut 
menandai batas akhir suatu event yang mencapai 72 event hingga pada tahun 2017.

"Gagasan dari Banyuwangi tersebut awalnya adalah untuk memperingati Hari Jadi Kabupaten Banyuwangi setiap 18 Desember hingga berlanjut sampai sekarang." (Fadli, 2017)

Penggalan wacana di atas terdapat kata tugas jenis preposisi yang menyatakan pembatasan yang ditandai dengan kata sampai. Kata sampai dalam kutipan tersebut menandai batas akhir gagasan dari Banyuwangi untuk memperingati hari jadinya yang masih berlanjut sampai sekarang.

\section{Preposisi yang Menyatakan Arah Tujuan}

Chaer (2009:109) menyatakan bahwa preposisi yang menyatakan arah tujuan yaitu kepada, akan, terhadap, dan ke. Preposisi yang menyatakan pembatasan ditemukan pada artikel opini "Melestarikan Budaya, Memandirikan Warga" yang ditandai dengan kata terhadap. Kata terhadap merupakan preposisi yang menandai suatu arah dari tujuan. Terdapat preposisi yang menyatakan pembatasan yang ditandai dengan kata terhadap sebanyak 1 data.

"Terkadang kita terlalu takut terhadap globalisasi yang merupakan bentuk imperialisme secara ekonomi dan budaya Barat." (Fadli, 2017)

Penggalan wacana di atas terdapat kata tugas jenis preposisi yang menyatakan arah tujuan yang ditandai dengan kata terhadap. Kata terhadap berfungsi sebagai arah suatu tujuan globalisasi yang tidak perlu ditakutkan lagi.

\section{Preposisi yang Menyatakan Pelaku}

Preposisi yang menyatakan pelaku ditemukan pada artikel opini "Melestarikan Budaya, Memandirikan Warga" yang ditandai kata oleh. Preposisi oleh merupakan kata depan yang digunakan untuk menyatakan pelaku perbuatan atau tindakan. Terdapat preposisi yang menyatakan pelaku yang ditandai dengan kata oleh sebanyak 1 data.

"Namun, sejauh ini Banyuwangi dengan penggalian lokalitas dan kreativitas dalam pengemasannya perlu dijadikan acuan bagi daerah lain. Tek heran jika Banyuwangi yang dipimpin Bupati Azwar Anas dinobatkan sebagai 'The Best Festival City' oleh Kementerian Pariwisata." (Fadli, 2017)

Penggalan wacana di atas terdapat kata tugas jenis preposisi yang menyatakan pelaku yang ditandai dengan kata oleh. Kata oleh menyatakan Kementerian Pariwisata sebagai pelaku yang menobatkan Bupati Azwar Anas dalam kategoti "The Best Festival City".

\section{Preposisi yang Menyatakan Asal}

Preposisi yang menyatakan asal ditemukan pada artikel opini "Melestarikan Budaya, Memandirikan Warga" yang ditandai dengan kata dari. Kata dari merupakan Preposisi yang menandai sesuatu tempat permulaan atau asal kedatangan. Terdapat 
preposisi yang menyatakan asal yang ditandai dengan kata dari sebanyak 3 data.

"Keseriusan

Banyuwangi

mengembangkan sektor pariwisata juga menyabet penghargaan dari Badan Pariwisata PBB (The United Nations World Tourism Organization/UNWTO) dalam ajang 12th UNWTO Awards Forum di Madrid, Spanyol, Januari 2016.” (Fadli, 2017)

Penggalan wacana di atas terdapat kata tugas jenis preposisi yang menyatakan asal yang ditandai dengan kata dari. Kata dari menandai awal mula daerah Banyuwangi yang mendapat penghargaan yaitu yang berasal dari Badan Pariwisata PBB.

\section{Hasil Identifikasi Jenis Kata Tugas Konjungsi}

Menurut Harimurti Kridalaksana dalam Kelas Kata Bahasa Indonesia (2009: 32), konjungsi merupakan kategori yang berfungsi untuk memperluas satuan lain dalam konstruksi hipotaktis dan menggabungkan satuan lain. Menurut Alwi, dkk. (2003:296), konjungsi merupakan jenis kata tugas yang berfungsi menghubungkan minimal dua satuan sintaksis yang sederajat: seperti satuan kata dengan kata, satuan frasa dengan frasa, atau satuan klausa dengan klausa. Konjungsi ada dua jenis, yaitu konjungsi intrakalimat dan konjungsi antarkalimat. Konjungsi intrakalimat meliputi konjungsi subordinatif, konjugsi koordinatif, dan konjungsi korelatif.

Konjungsi ditemukan pada artikel opini "Melestarikan Budaya, Memandirikan Warga" dalam surat kabar Jawapos berupa konjungsi subordinatif yaitu konjungsi yang, karena, sehingga, hingga, untuk, bahwa, jika, dan sebagaimana. Kemudian konjungsi koordinatif berupa konjungsi dan, tetapi, atau, sebagai, dan serta. Serta konjungsi antarkalimat berupa konjungsi namun dan bahkan.

Tabel 2. Jumlah Kata Tugas Jenis Konjungsi dalam Artikel

\begin{tabular}{|l|l|l|}
\hline No & Jenis Konjungsi & Jumlah \\
\hline 1 & Konjungsi Subordinatif & 21 data \\
\hline 2 & Konjungsi Koordinatif & 19 data \\
\hline 3 & Konjungsi Antarkalimat & 2 data \\
\hline \multicolumn{2}{c}{ Total } & $\mathbf{4 2}$ data \\
\hline
\end{tabular}

\section{Konjungsi Subordinatif}

Menurut Sugono (dalam Purwiati, 2015:134), konjungsi subordinatif adalah kata yang menghubungkan anak kalimat dan induk kalimat. Selain itu, Alwi, dkk. (2003:299) juga mengemukakan bahwa konjungsi subordinatif merupakan kata hubung yang berfungsi menghubungkan paling sedikit dua klausa dan klausa tersebut tidak berada dalam kategori sederajat. Konjungsi subordinatif ditemukan pada artikel opini "Melestarikan Budaya, Memandirikan Warga" yang ditandai dengan kata yang, karena, sehingga, hingga, 
untuk, bahwa, jika, dan sebagaimana. Terdapat konjungsi subordinatif yang ditandai dengan kata yang sebanyak 9 data, kata karena sebanyak 1 data, kata sehingga sebanyak 1 data, kata hingga sebanyak 2 data, kata untuk sebanyak 5 data, kata bahwa sebanyak 1 data, kata jika sebanyak 1 data, dan kata sebagaimana sebanyak 1 data.

"Perkembangan komunikasi yang semakin global membuat semua semakin mudah terkoneksi." (Fadli, 2017)

Kata yang pada penggalan wacana di atas berfungsi sebagai konjungsi subordinatif yaitu kata hubung untuk menghubungkan setidaknya dua klausa yang tidak memiliki relasi sintaksis yang sederajat. Kata yang pada kutipan di atas berfungsi menghubungkan klausa perkembangan komunikasi dengan klausa semakin global.

"Batas antara global dan lokal semakin luntur karena semua masuk dalam arena global.” (Fadli, 2017)

Kata karena pada penggalan wacana di atas berfungsi sebagai konjungsi berdasarkan sebab. Konjungsi tersebut menyatakan peristiwa yang terjadi akibat suatu sebab. Kata karena pada kutipan di atas menandai adanya peristiwa batasan antara global dan lokal yang semakin pudar akibat meluasnya arena global.

"Apa pun dapat ditampilkan dan semakin terbuka untuk direplikasi, termasuk dalam budaya. Dalam hal ini, dapat dilihat bagaimana aliran-aliran global tersebut bergerak sehingga menimbulkan berbagai perpaduan budaya." (Fadli, 2017)

Kata sehingga pada penggalan wacana di atas berfungsi sebagai konjungsi subordinatif yang menyatakan akibat. Kata sehigga pada kutipan di atas menyatakan akibat perpaduan budaya disebabkan oleh aliran-aliran global suatu budaya.

"Sejak 2012 hingga saat ini, Banyuwangi selalu mengadakan festival budaya dengan nama 'Festival Banyuwangi" atau dikenal dengan B-Fest." (Fadli, 2017)

Kata hingga pada penggalan wacana di atas berfungsi sebagai konjungsi subordinatif yaitu kata penanda hubung untuk menyatakan batas tertentu. Kata hingga pada kutipan di atas menandai batas waktu penyelenggaraan festival budaya yang berlangsung sejak tahun 2019 sampai saat ini.

"Menurut Amartya Sen (2012), pembangunan seharusnya merupakan proses yang memfasilitasi manusia untuk mengembangkan pilihannya." (Fadli, 2017)

Kata untuk pada penggalan wacana di atas berfungsi sebagai konjungsi subordinatif yaitu kata penghubung menyatakan tujuan atau maksud. Kata untuk pada kutipan di atas menandai maksud dari pembangunan yang memfasilitasi manusia bertujuan mengembangkan pilihannya. 
"Poin tersebut menekankan bahwa pemahaman atas kearifan lokal harus dijadikan acuan pembangunan di daerah." (Fadli, 2017)

Kata bahwa pada penggalan wacana di atas berfungsi sebagai kata penghubung dari penjelasan mengenai suatu peristiwa yang terjadi. Kata bahwa pada kutipan di atas menghubungkan penjelasan terkait pemahaman kearifan lokal.

"Tak heran jika Banyuwangi yang dipimpin Bupati Azwar Anas dinobatkan sebagai 'The Best Festival City', oleh Kementerian Pariwisata." (Fadli, 2017)

Kata jika pada penggalan wacana di atas sebagai kata penghubung antara dua klausa untuk menandai persyaratan.

"Ada tiga aspek pembentuk suatu ruang: aktivitas sosial-ekonomi-budaya, sistem nilai, dan bentang fisik ruang. Sebagaimana yang disebut Foucault (1967) sebagai heterotopia atau ruang-ruang yang lain.” (Fadli, 2017)

Kata sebagaimana pada penggalan wacana di atas berkedudukan sebagai konjungsi subordinatif yaitu kata sambung yang menghubungkan setidaknya dua klausa yang tidak memiliki hubungan satuan sintaksis yang sederajat.

\section{Konjungsi Koordinatif}

Menurut Rahardi (dalam Mutiadi 2005:18), konjungsi koordinatif adalah kata penghubung yang menghubungkan dua unsur kebahasaan atau yang cenderung sama tataran atau tingkat kepentingannya. Alwi, dkk. (2003:297) juga mengemukakan konjungsi koordinatif merupakan kata hubung yang menghubungkan setidaknya dua unsur satuan sintaksis yang berkedudukan sama pentingnya. Jenis konjungsi koordinatif meliputi kata dan sebagai penanda hubungan penambahan, kata serta sebagai penanda hubungan pendampingan, kata atau sebagai penanda hubungan pemilihan, kata tetapi sebagai penanda hubungan yang menyatakan perlawanan, kata melainkan sebagai penanda hubungan yang menyatakan perlawanan, kata padahal sebagai penanda hubungan yang menyatakan pertentangan, dan kata sedangkan sebagai penanda hubungan yang menyatakan pertentangan. Konjungsi koordinatif ditemukan pada artikel opini "Melestarikan Budaya, Memandirikan Warga" yang ditandai dengan kata dan, tetapi, atau, sebagai, dan serta. Terdapat konjungsi koordinatif yang ditandai dengan kata dan sebanyak 11 data, kata tetapi sebanyak 3 data, kata atau sebanyak 3 data, kata sebagai sebanyak 1 data, dan kata serta sebanyak 1 data

"Menurut Amartya Sen (2012), pembangunan seharusnya merupakan proses yang memfasiliasi manusia untuk mengembangkan pilihannya. Menurut dia, dengan hal tersebut, manusia mampu mengoptimalkan potensinya dengan 
sempurna. Pembangunan harus bisa melihat anyaman antara sumber daya alam dan sumber daya budaya (Sudaryono, 2007).' (Fadli, 2017)

Kata dan pada penggalan wacana di atas berfungsi sebagai kata penghubung satuan kata, frasa atau klausa. Kata dan pada kutipan di atas menghubungkan frasa sumber daya alam dengan frasa sumber daya budaya.

"Perkembangan komunikasi yang semakin global membuat semua semakin mudah terkoneksi. Arus informasi begitu cepat melampaui batas kewilayahan. Pertukaran informasi bergerak tanpa sekat. Tidak hanya dalam ekonomi, tetapi juga dalam segala hal.” (Fadli, 2017)

Kata tetapi pada penggalan wacana di atas berfungsi sebagai konjungsi koordinatif yaitu kata menghubungkan dua unsur yang berlawanan. Kata tetapi pada kutipan di atas menghubungkan unsur ekonomi dengan unsur segala hal sebagai sesuatu yang berlawanan.

"Sebagaimana yang disebut Foucault (1967) sebagai heterotopia atau ruang-ruang yang lain." (Fadli, 2017)

Kata atau pada penggalan wacana di atas berfungsi sebagai penanda hubungan pemilihan. Kata atau pada kutipan di atas berfungsi menghubungkan unsur pemilihan dua unsur yaitu heterotopia atau ruang-ruang lain.
"Tak heran jika Banyuwangi yang dipimpin Bupati Azwar Anas dinobatkan sebagai 'The Best Festival City' oleh Kementerian Pariwisata." (Fadli, 2017)

Kata sebagai pada penggalan wacana di atas berfungsi sebagai kata hubung untuk menyatakan status atau menjadi. Kata sebagai pada kutipan di atas menyatakan Bupati Azwar Anas menjadi atau menduduki kategori "The Best Festival City".

"Daerah lain juga melakukan kebijakan serupa dalam mengelola kearifan lokalnya. Misalnya, Banjarnegara dengan Dieng Culture Festival (DCF), Jember dengan Jember Fashion Carnaval (JFC), serta Lumajang dengan Festival Semerunya." (Fadli, 2017)

Kata serta pada penggalan wacana di atas berfungsi sebagai konjungsi penanda hubungan pendampingan yag terletak di antara dua klausa.

\section{Konjungsi Antarkalimat}

Menurut Alwi, dkk. (2003:300), konjungsi antarkalimat merupakan kata hubung yang berfungsi menghubungkan satu satuan kalimat dengan satuan kalimat yang lainnya. Konjungsi ini selalu digunakan untuk memulai kalimat yang baru dengan penulisan huruf pertamanya berupa pemakaian huruf kapital. Konjungsi antarkalimat selalu mengawali kalimat yang dihubungkan (Muchlis dalam Melia 2010:115). Konjungsi antarkalimat ditemukan pada artikel opini 
"Melestarikan Budaya, Memandirikan

Warga" yang ditandai dengan kata namun dan bahkan. Terdapat konjungsi koordinatif yang ditandai dengan kata namun sebanyak 1 data dan kata bahkan sebanyak 1 data

"Misalnya, Banjarnegara dengan

Dieng Culture Festival (DCF), Jember dengan Jember Fashion Carnaval (JFC), serta Lumajang dengan Festival Semeru-nya. Namun, sejauh ini Banyuwangi dengan penggalian lokalitas dan kreativitas dalam pengemasannya perlu dijadikan acuan bagi daerah lain." (Fadli, 2017)

Kata namun pada penggalan wacana di atas berfungsi sebagai penghubung antarkalimat yang menandai perlawanan.

"Kondisi tersebut berdampak terhadap perubahan tatanan sosial. Batas antara global dan lokal semakin luntur karena semua masuk dalam arena global. Bahkan, lebih dari itu, Gidden (1991) menyatakan, ini untuk kali pertama dalam sejarah manusia, 'diri' dan 'masyarakat' saling berhubungan di dalam satu lingkungan global.” (Fadli, 2017)

Kata bahkan pada penggalan wacana di atas berfungsi sebagai kata yang menghubungkan setidaknya dua bagian kalimat untuk menyatakan kategori penguatan terhadap sesuatu.

\section{Pronomina}

Kridalaksana (dalam Karmila, 2017:195) mengartikan pronomina sebagai kategori yang berfungsi menggantikan nomina atau kata benda yang berupa orang. Menurut Alwi, dkk. (2003:249), pronomina merupakan kata ganti yang difungsikan untuk merujuk kepada bentuk nomina lain. Berdasarkan fungsinya, pronomina menduduki posisi yang umumnya diduduki oleh nomina, seperti objek, subjek dan dalam kalimat tertentu dipredikat. Karakteristik lain yang dimiliki kata tugas pronomina yaitu acuannya dapat berpindah-pindah karena menyesuaikan siapa yang menjadi pendengar atau siapa yang menjadi objek pembicaraan. Pronomina terbagi dalam tiga macam, yakni (a) pronomina persona pertama, pronomina penunjuk, dan (c) pronomina penanya.

Pronomina ditemukan pada artikel opini "Melestarikan Budaya, Memandirikan Warga" dalam surat kabar Jawapos berupa jenis pronomina penunjuk umum, pronomina ketiga tunggal, dan pronomina persona pertanma jamak.

Tabel 3. Jumlah Kata Tugas Jenis Pronomina dalam Artikel

\begin{tabular}{|c|c|c|}
\hline No & Jenis Pronomina & Jumlah \\
\hline 1 & $\begin{array}{l}\text { Jenis pronomina penunjuk } \\
\text { umum }\end{array}$ & 8 data \\
\hline 2 & $\begin{array}{l}\text { Jenis pronomina ketiga } \\
\text { tunggal }\end{array}$ & 2 data \\
\hline
\end{tabular}




\begin{tabular}{|c|l|l|}
\hline 3 & $\begin{array}{l}\text { Jenis pronomina persona } \\
\text { pertama jamak }\end{array}$ & 2 data \\
\hline \multicolumn{2}{|c|}{ Total } & $\mathbf{1 2}$ data \\
\hline
\end{tabular}

\section{Pronomina Penunjuk Umum}

Pronomina penunjuk umum ditandai dengan kata ini dan kata itu. Kata ganti penunjuk umum ini merujuk pada sasaran yang berdekatan dengan penulis atau pengungkap (Hastuti, 2019). Acuan yang dipakai dari sesuatu yang agak jauh dari penulis atau pengungkap, terjadi pada masa lalu, atau mengacu kepada informasi yang telah disampaikan, maka digunakan kata ganti itu (Septianingrum, 2019:105). Pronomina penunjuk umum ditemukan pada artikel opini "Melestarikan Budaya, Memandirikan Warga" yang ditandai dengan kata ini. Terdapat pronomina penunjuk umum yang ditandai dengan kata ini sebanyak 8 data.

"Apa pun dapat ditampilkan dan semakin terbuka untuk direplikasi, termasuk dalam budaya. Dalam hal ini, dapat dilihat bagaimana aliran-aliran global tersebut bergerak sehingga menimbulkan berbagai perpaduan budaya." (Fadli, 2017)

Kata ini pada penggalan wacana di atas merujuk pada sasaran yang berdekatan dengan penulis dan dinyatakan untuk waktu yang akan datang.

\section{Pronomina Persona Ketiga Tunggal}

Pronomina persona sebagai referensi yang ditunjukkan oleh kata ganti persona berganti-ganti tergantung pada peran yang dibawakan oleh peserta tindak tutur (Purwo dalam Maisuri, 2018). Pronomina persona ketiga adalah pronomina yang mengacu pada orang yang dibicarakan. Pronomina persona yang mengacu pada satu orang disebut pronomina ketiga tunggal (Ruriana, 2018:234). Pronomina persona ketiga tunggal ditemukan pada artikel opini "Melestarikan Budaya, Memandirikan Warga" yang ditandai dengan kata ia dan dia. Terdapat pronomina penunjuk umum yang ditandai dengan kata $i a$ sebanyak 1 data dan kata dia sebanyak 1 data.

"Sebelumnya, ada pandangan homogenisasi budaya secara global yang dilakukan negara dominan. Dalam pandangan George Ritzer (2012), homogenisasi memang terjadi, tetapi menyebar di seluruh dunia dengan bentuk yang kosong (nothing). Kekosongan tersebut terjadi karena ia menyebar dalam bentuknya saja, tetapi tak memiliki muatan (something)." (Fadli, 2017)

Kata ia pada penggalan wacana di atas berfungsi sebagai kata ganti orang yang mengacu kepada orang yang tidak dibicarakan, tidak termasuk kawan pembicara.

"Menurut Amartya Sen (2012), pembangunan seharusnya merupakan proses yang memfasilitasi manusia untuk mengembangkan pilihannya. Menurut dia, dengan hal tersebut, manusia mampu 
mengoptimalkan potensinya sempurna." (Fadli, 2017)

Kata dia pada penggalan wacana di atas berperan sebagai kata ganti yang mengacu kepada orang yang tidak dibicarakan, tidak termasuk kawan pembicara.

\section{Pronomina Persona Pertama Jamak}

Pronomina persona pertama adalah pronomina yang mengacu pada diri sendiri (Ruriana, 2018:234). Pronomina persona pertama jamak ditemukan pada artikel opini "Melestarikan Budaya, Memandirikan Warga" yang ditandai ini. Terdapat pronomina penunjuk umum yang ditandai dengan kata kita sebanyak 2 data.

"Terkadang kita terlalu takut terhadap globalisasi yang merupakan bentuk imperialisme secara ekonomi dan budaya Barat." (Fadli, 2017)

Kata kita pada penggalan wacana di atas berfungsi sebagai kata ganti yang melingkupi tidak hanya pembicara atau tidak hanya penulis, tetapi juga melingkupi pendengar atau pembaca, bahkan boleh jadi pihak lain.

\section{SIMPULAN}

Berdasarkan analisis tentang jenisjenis kata tugas pada artikel opini "Melestarikan Budaya, Memandirikan Warga", ditemukan tiga penggunaan jenis kata tugas, yaitu konjungsi, preposisi, dan pronomina. Konjungsi yang ditemukan berupa konjungsi subordinatif yaitu konjungsi yang; karena; sehingga; hingga; untuk; bahwa; jika; dan sebagaimana, konjungsi koordinatif berupa konjungsi dan; tetapi; atau; sebagai; dan serta, dan konjungsi antarkalimat berupa konjungsi namun dan bahkan. Preposisi yang ditemukan berupa preposisi yang menyatakan cara yaitu dengan, preposisi yang menyatakan tempat yaitu $d i$ dalam; di dunia luar; di daerah, preposisi yang menyatakan pembatasan yaitu hingga dan sampai, preposisi yang menyatakan arah tujuan yaitu terhadap, preposisi yang menyatakan pelaku yaitu oleh, dan preposisi yang menyatakan asal yaitu dari. Pronomina yang ditemukan berupa jenis pronomina penunjuk umum yaitu ini, pronomina persona pertama jamak yaitu kita, dan pronomina ketiga tunggal yaitu dia dan ia. Kata tugas yang ditemukan dalam artikel ini memperhatikan penggunaannya dalam penyusunan kalimat sehingga memfungsikan peran kata tugas sebagai sarana yang menghadirkan kegramatikalan kalimat yang menyusun paragraf. Penggunaan kata tugas pada artikel ini menyusun kepaduan kalimat sehingga informasi yang disampaikan dapat dipahami pembaca.

\section{DAFTAR PUSTAKA}

Chaer, A. (2009). Sintaksis Bahasa Indonesia. Jakarta: Rineka Cipta. 
Dewi, W. W. (2009). Kelas Kata Bahasa Indonesia. Klaten: Intan Pariwara.

Fadli, M. (2017, Desember 17). Melestarikan Budaya, Memandirikan Warga. Diakses dari URL https://www.jawapos.com/opini/sudutpandang/17/12/2017/melestarikanbudaya-memandirikan-warga/

Hasanah, M. (2017). Argumentasi dalam Artikel Opini Surat Kabar Media Indonesia. Jurnal Kajian Perpustakaan dan Informasi. (1). 12-22. Diakses dari URL http://journal2.um.ac.id/index.php/biblioti $\mathrm{ka} /$ article/view/2302

Hastuti, D. (2019). Analisis Fitur Kebahasaan Teks Tajuk Rencana Harian Suara Merdeka dan Kompas Edisi 1 sampai dengan 30 April 2017. Jurnal Sastra Indonesia. (8). 138-147. Diakses dari URL

https://journal.unnes.ac.id/sju/index.php/js i/article/view/27202

Isnaini, L. (2018). Penggunaan Teks Eksposisi pada Teks Argumentasi Siswa Kelas X Semester Ganjil SMA Negeri 3 Bandar Lampung Tahun Pelajaran 2018/2019. Jurnal Ilmiah Mahasiswa Pendidikan Bahasa dan Sastra Indonesia. (3). 1-15. Diakses dari URL http://jurnal.fkip.unila.ac.id/index.php/BI NDO1/article/view/8137

Karmila, Y. (2017). Pronomina Bahasa Devayan. Jurnal Ilmiah Mahasiswa Jurusan PBSI. (2). 192-206. Diakses dari URL

http://www.jim.unsyiah.ac.id/pbsi/article/ view/6973

Maisuri , A. (2018). Penggunaan Deiksis Pronomina, Tempat, dan Waktu pada Novel Genduk Karya Sundari Mardjuki. Jurnal Pendidikan dan Pembelajaran Khatulistiwa. (7). Diakses dari URL https://jurnal.untan.ac.id/index.php/jpdpb/ article/view/24681

Masitoh, S. I. (2019). Kata Tugas Bahasa Sunda dalam Karangan Laporan Peristiiwa. Jurnal Kajian Bahasa, Sastra, dan Budaya Daerah serta Pengajarannya. (10). 149-160. Diakses dari URL https://ejournal.upi.edu/index.php/lokabas a/article/view/21362

Mutiadi, A. D. (2014). Analisis Konjungsi Koordinatif dan Konjungsi Subordinatif pada Novel "Gurita David" Karya Willy W. Jurnal Bahasa dan Sastra Indonesia. (4). Diakses dari URL

https://journal.uniku.ac.id/index.php/FON /article/view/169

Pratami, I. (2016). Penggunaan Kata Tugas dalam Teks Eksposisi Siswa Kelas VII SMP Negeri 2 Bukittinggi. Jurnal Pendidikan Bahasa dan Sastra Indonesia. (5). 161-168. Diakses dari URL http://repository.unp.ac.id/19455/

Purwiati, I. A. (2015). Konjungsi

Subordinatif dalam Buku Teks Pelajaran SLTA: Analisis Bentuk, Distribusi, dan Makna. Aksara. (27). 133-150. Diakses dari URL

https://aksara.kemdikbud.go.id/jurnal/inde x.php/aksara/article/view/180

Ruriana, P. (2018). Pronomina Persona dan Bentuk-Bentuk Lain Pengganti Pronomina Persona dalam Bahasa Blambangan. Metalingua. (16). 231-246. Diakses dari URL http://metalingua.kemdikbud.go.id/jurnal/i ndex.php/metalingua/article/view/254

Septianingrum. (2019). Jenis dan Fungsi Pronomina Penunjuk pada Kalimat Majemuk Setara dalam Novel Arah Langkah Karya Fiersa Besari dan Implementasinya sebagai Bahan Ajar di SMA. Jurnal Pendidikan Bahasa dan Sastra Indonesia. (2). 95-108. Diakses dari URL 
http://jom.untidar.ac.id/index.php/repetisi/ article/view/772

Sugiarti, R. (2018). Analisis Kesalahan Penggunaan Preposisi dan Pungtuasi dalam Karangan Narasi Siswa. Jurnal Keilmuan dan Kependidikan Dasar. (10). 125-134. Diakses dari URL http://jurnal.uinbanten.ac.id/index.php/pri mary/article/view/1284

Suhardi. (2013). Dasar-Dasar Ilmu Sintaksis Bahasa Indonesia. Yogyakarta: Ar-Ruzz Media.

Alwi, Hasan dkk. 2003. Tata Bahasa Baku Indonesia. Jakarta: Balai Pustaka.

Utomo, A. P. dkk. (2019). Kesalahan Bahasa pada Manuskrip Artikel Mahasiswa di Jurnal Sastra Indonesia. Jurnal Sastra Indonesia. (3). 234-241. Diakses dari URL https://journal.unnes.ac.id/sju/index.php/js i/article/view/36028/14877

Zulfatun, A. (2019). Penggunaan Preposisi dalam Paragraf Narasi Siswa Kelas X-1 SMA PGRI 2 Bandung. Al-Hikmah Jurnal Studi Keislaman. (9). 16-29. Diakses dari URL http://ejournal.kopertais4.or.id/pantura/ind ex.php/alhikmah/article/view/3412

Febriani, M. (2016, April 6). Diambil kembali dari http://blog.unnes.ac.id/meinafebri/2016/0 4/07/alat-alat-sintaktis/

Yogi, Saputra. (2020, 1 Maret). Kata Tugas. Tertulis pada https://majalahpendidikan.com/kata-tugas/ 